CARAKA: Indonesian Journal of Communications, vol. 2(1), 2021, 1-7

\title{
Manajemen Komunikasi Krisis Universitas XXY Menghadapi Pandemi COVID-19
}

\author{
https://doi.org/10.25008/caraka.v2i1.52 \\ Aris Sumartono, Umaimah Wahid \\ Universitas Budi Luhur, Jakarta - Indonesia
}

\begin{abstract}
The COVID-19 pandemic in XXY University has made the academic community uncomfortable. Unclear information related to victims infected with COVID-19 causes feelings of anxiety and leads to negative thinking. This condition raises the question, how is XXY University's crisis management process in dealing with clusters of the spread of the COVID-19 virus on campus. The theory used is Situational Crisis Communication Theory. His research used a qualitative approach, with data collection techniques through interviews and collecting documents. The results showed that the crisis management at XXY University in the pre-crisis stage was to monitor media coverage. When a crisis occurs, the diminish strategy is used to reduce the negative impact of the crisis. The trick is to collaborate with RW administrators, campus RTs, mass media, publication of press releases through websites, communicating with local government, police, transportation services, and utilizing traditional and digital media. At the post-crisis stage, XXY University's communication action is to issue a number of policies for the prevention of COVID-19. The conclusion of this study is that XXY University's policy of delivering information through circulars and internal memos, succeeded in reducing negative sentiments of campus residents, and reducing their anxiety at work.
\end{abstract}

Keywords: Academic community; crisis management; COVID-19; unclear information; XXY University.

\section{ABSTRAK}

Pademi COVID-19 di lingkungan Universitas XXY membuat warga sivitas akademika tidak nyaman. Ketidakjelasan informasi terkait korban terinfeksi COVID-19 menimbulkan perasaan cemas dan mengarah ke negative thinking. Kondisi itu menimbulkan pertanyaan, bagaimana proses manajemen krisis Universitas XXY dalam menangani cluster penyebaran virus COVID-19 di kampus. Teori yang digunakan adalah Situational Crisis Communication Theory. Penelitiannya memakai pendekatan kualitatif, dengan teknik pengumpulan data melalui wawancara dan mengumpulkan dokumen. Hasil penelitian menunjukkan, manajemen krisis Universitas XXY pada tahap pre-krisis adalah memonitor pemberitaan media. Saat krisis terjadi, dipakai strategi diminish guna mengurangi dampak negatif krisis. Caranya, menjalin kerja sama dengan pengurus RW, RT kampus, media massa, publikasi siaran pers melalui website, berkomunikasi dengan Pemerintahan daerah, Kepolisian, Dinas Perhubungan, serta memanfaatkan media tradisional dan digital. Pada tahap post-krisis, tindakan komunikasi Universitas XXY adalah mengeluarkan sejumlah kebijakan untuk pencegahan COVID-19. Kesimpulan penelitian ini adalah, kebijakan Universitas XXY berupa penyampaian informasi melalui surat edaran dan memo internal, berhasil menurunkan sentimen negatif warga kampus, dan mengurangi rasa cemas mereka dalam bekerja. Kata kunci: Komunitas kampus, manajemen krisis, COVID-19, Informasi tidak pasti, universitas XXY

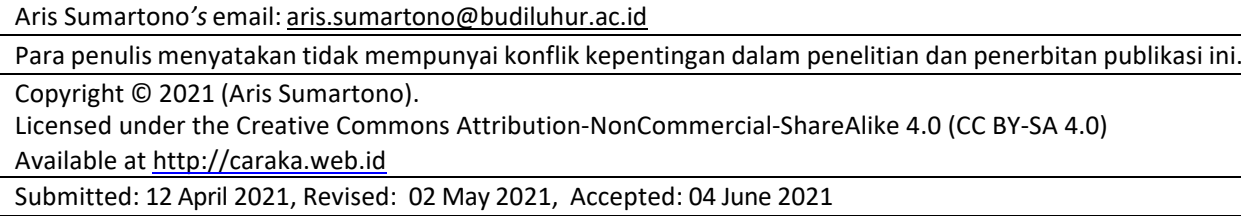




\section{PENDAHULUAN}

Pandemi COVID-19 membawa banyak perubahan berperilaku dan bersosialiasi di masyarakat. COVID-19 juga telah menimbulkan berbagai dampak di segala bidang. Salah satu yang terdampak adalah dunia pendidikan. Para pelajar dan mahasiswa tidak dapat melakukan pembelajaran tatap muka, namun sekolah dan perguruan tinggi tetap harus beroperasi sehingga guru, dosen, peneliti, dan tenaga kependidikan secara bergantian datang ke sekolah atau kampus guna menjalankan tugas mereka. Kondisi itu membuat mereka berada dalam kondisi was-was karena setiap saat bisa terpapar COVID-19, sebagaimana telah terjadi di sejumlah sekolah maupun perguruan tinggi.

Korban COVID-19 di Indonesia terus bertambah dari hari ke hari sejak diumumkan pertamakali 2 Mei 2020. Data per 23 November 2020, kasus terkonfirmasi COVID-19 sebanyak 797.723 dengan 23.520 kematian, dan sembuh 659.437 orang (Kompas.com, 2020b). Hingga 26 Juni 2021, data menunjukkan, pasien positif Corona 2.115.304 orang (Kompas.com - 27/06/2021, 18:36 WIB). COVID-19 adalah penyakit baru yang belum pernah diidentifikasi sebelumnya. Virus penyebab COVID-19, dinamakan Sars-CoV-2, ditularkan dari hewan ke manusia. Hewan yang menjadi sumber penularan COVID-19 belum diketahui. Pada kasus yang parah, COVID-19 dapat menyebabkan pneumonia, sindrom pernapasan akut, gagal ginjal, bahkan kematian (Kemkes, 2020).

Presiden Joko Widodo mengumumkan untuk pertama kali dua kasus infeksi COVID-19 yang terjadi di Indonesia, 2 Maret 2020 (Kompas.com, 2020a). Wabah ini telah ditetapkan sebagai darurat kesehatan global. Virus ini membuat semua kegiatan manusia terhambat (C. Sohrabi, 2020). Pemerintah Indonesia sejauh ini telah mengambil sejumlah langkah dan kebijakan guna mengatasi pandemi ini (Buana, 2020), namun jumlah kasus terus meningkat.

Tidak hanya jumlah kasus COVID-19 yang meningkat, jumlah penderita COVID-19 dan korban meninggal akibat COVID-19 juga bertambah, termasuk di lingkungan Universitas XXY. Penerapan kebijakan WFH diberlakukan di Universitas XXY sejak Maret 2020 sebagai langkah pencegahan penyebaran virus COVID-19. Namun seiring berjalannya waktu, terjadi perubahan kebijakan, mengikuti perubahan kebijakan Pemerintah, mulai dari Pembatasan Sosial Berskala Besar (PSBB) sampai dengan kebijakan New Normal: beberapa sektor usaha boleh beroperasi namun harus memperhatikan social distancing dan protokol Kesehatan yang ketat.

Kebijakan New Normal yang diterapkan oleh Universitas XXY berupa bekerja dari rumah atau Work From Home (WFH) dan juga non WFH. Pemberlakuan masuk kerja diatur oleh masing-masing fakultas dengan jadwal kerja dua kali dalam satu minggu bekerja di kampus dan sisanya bekerja di rumah. Kebijakan ini di satu sisi dapat meningkatkan kinerja karyawan yang sudah mulai tidak produktif, namun di sisi lain menimbulkan cluster baru penyebaran virus COVID-19. Hal ini terbukti dengan adanya beberapa karyawan terjangkit virus COVID-19 dan adanya korban jiwa.

Sejak diberlakukannya kebijakan WFH dan non WFH, jumlah korban COVID-19 sudah mencapai kurang lebih 10 orang dengan tiga orang meninggal dunia. Dengan adanya korban baik yang terpapar COVID-19 maupun meninggal dunia, menjadikan warga Universitas XXY merasa tidak nyaman. Ketidakjelasan informasi yang didapat karyawan terkait korban COVID-19 menimbulkan perasaan cemas, mengarah ke negative thinking dan sentimen negatif.

Definisi krisis merupakan kejadian besar yang memberikan hasil negatif dan berpotensi mempengaruhi organisasi, perusahaan, atau industri, serta publiknya, produk, layanan, atau nama baik. Berdasarkan definisi tersebut, munculnya cluster penyebaran virus COVID-19 di kantor dan ketidaktransparan informasi terkait karyawan yang terpapar virus COVID-19 di Universitas XXY dapat digolongkan sebagai krisis. Peristiwa tersebut memberikan sentimen negatif bagi nama baik Universitas XXY. Manajemen krisis dan transparansi informasi sangat diperlukan guna menelusuri orang-orang yang terpapar COVID-19 demi memutus mata rantai penyebaran virus COVID-19, di 
Universitas XXY.

Bagian Public Relations dalam suatu perusahaan ataupun lembaga memiliki tugas besar untuk mengelola komunikasi di sebuah organisasi, termasuk penanganan krisis komunikasi. Tindakan yang dilakukan oleh public relations fokus pada persiapan krisis sebagai strategi untuk meminimalkan kerusakan pada reputasi perusahaan. Kegiatan yang dianggap penting saat melakukan komunikasi krisis adalah persiapan manajemen krisis. Dari penjelasan tersebut, seharusnya sosok public relations di Universitas XXY dapat memberikan peran penanganan krisis dan melakukan kegiatan manajemen krisis di fase pertama (W.T. Coombs \& \& Holladay, 2010).

Adanya indikasi masalah dan latar belakang ini menghasilkan pertanyaan penelitian tentang bagaimana sebenarnya proses manajemen krisis yang dilakukan oleh Universitas XXY, dalam menangani krisis komunikasi akibat munculnya cluster penyebaran virus COVID-19 di sana.

Penelitian ini bertujuan untuk mengetahui cara atau strategi manajemen krisis yang dilakukan oleh public relations Universitas XXY dalam menangani penyebaran virus COVID-19 melalui cluster kantor. Adapun manfaat teoritis dari hasil penelitian ini diharapkan dapat menjadi referensi dan acuan bagi penelitian sejenis terkait manajemen krisis.

\section{KERANGKA TEORI}

Penggunaan teori Situational Crisis Communication Theory dipilih untuk memperkaya strategi manajemen krisis yang bisa dilakukan oleh public relations dalam menjaga reputasi organisasi (Yulianti \& Boer, 2020). Kegiatan penanganan krisis yang dilakukan oleh pihak public relations yaitu menerapkan pelaksanaan manajemen krisis.

Coombs \& Holladay menjelaskan manajemen krisis sebagai upaya untuk mencegah atau mengurangi hasil negatif dari krisis untuk melindungi organisasi serta para stakeholder, membagi manajemen krisis menjadi tiga bagian yaitu pre-crisis, crisis dan post-crisis.

Berikut ini penjelasan dari masing-masing tahapan (W.T. Coombs \& \& Holladay, 2010); Precrisis merupakan tahap sebelum terjadi krisis, tindakan yang dilakukan yaitu mengumpulkan seluruh informasi tentang resiko krisis, menentukan respon yang dilakukan saat krisis dan mempersiapkan sosok terpercaya, yang akan memberikan informasi pada publik.

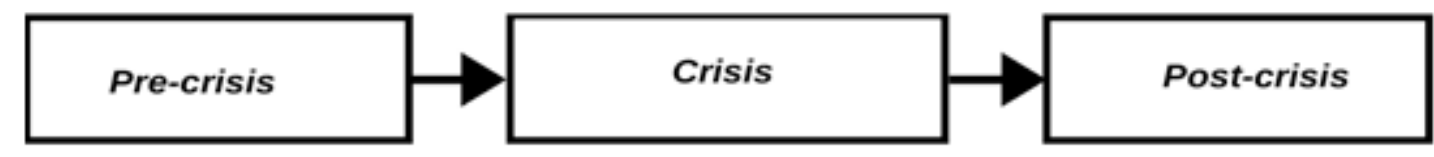

Gambar 1. Tahapan Manajemen Krisis

Sumber: Coombs \& Holladay, 2010

Selanjutnya adalah crisis. Organisasi yang sedang berada dalam situasi krisis, harus memberikan respons yang tepat, sehingga krisis bisa tertangani dengan baik. Untuk memperdalam penanganan yang diberikan pada tahapan krisis, digunakan teori Situational Crisis Communication Theory (SCCT).

SCCT dikemukakan pertama kali oleh Timothy Coombs tahun 1995. Teori ini didasari oleh peristiwa krisis yang memberikan dampak negatif bagi organisasi maupun stakeholder sehingga diperlukan tanggung jawab untuk mengatasinya.

Media menjadi hal penting yang bisa dimanfaatkan ketika organisasi mengalami krisis. Juru bicara atau spokesperson harus bertemu dengan media pada tahap awal krisis untuk menyebarluaskan informasi dan berpartisipasi dalam membingkai krisis. Pertanyaan media harus 
dijawab dengan cepat, akurat, terbuka dan konsisten. Coombs \& Holladay menjelaskan, untuk menangani krisis komunikasi, organisasi dapat menggunakan new media, seperti website perusahaan ataupun pemberitaan media online, kemudian social network seperti web blogs, twitter, podcast, youtube dan email.

Menurut Coombs \& Holladay, setelah organisasi melakukan crisis response, baru dapat dilihat bagaimana affect atau pengaruhnya kepada reputation organizational dan behavioral intentions dari publik (W.T. Coombs \& \& Holladay, 2010). Tahap terakhir pada manajemen krisis adalah postcrisis. Coombs \& Holladay menjelaskan post-crisis sebagai pembelajaran yang diterima organisasi setelah terjadi krisis. Pada tahap ini tetap dibutuhkan komunikasi, untuk mengubah dan menyediakan pesan yang dibutuhkan setelah krisis berlangsung (W.T. Coombs \& Holladay, 2010).

\section{METODOLOGI}

Penelitian ini menggunakan pendekatan kualitatif, karena ingin menggambarkan salah satu peristiwa yang ada dalam kehidupan sosial. Menurut West \& Turner, pendekatan kualitatif untuk menggambarkan detail tentang orang, tindakan, dan peristiwa dalam kehidupan sosial (Turner, Lynn $\mathrm{H}$ and West, 2010), kemudian, untuk jenis metode yang dipakai yaitu deskriptif.

Cara mengolah data metode deskriptif, data yang telah terhimpun diolah kemudian dianalisis dengan mengkoding istilah/frase/narasi tertentu yang diambil dari data deskriptif. Sebelum melakukan penelitian, peneliti membuat rumusan masalah berupa pertanyaan-pertanyaan yang umumnya dimulai dengan kata tanya 'apa'.

Rumusan masalah tersebut akan dijawab dengan cara mendeskripsikan. Teknik analisis data yang digunakan dalam penelitian kualitatif mencakup transkip hasil wawancara, reduksi data, analisis, interpretasi data dan triangulasi.

Perolehan data primer dalam penelitian ini diperoleh secara lansung melalui wawancara dengan petinggi Universitas XXY yaitu Ketua Yayasan sebagai key informan 1, Rektor Universitas XXY sebagai key informan 2, dan Direktur Kerja Sama dan Hubungan Masyarakat Universitas XXY sebagai informan.

Teknik pengumpulan data yang digunakan dalam penelitian ini adalah wwancara, observasi, dan studi pustaka.

\section{HASIL PENELITIAN}

Manajemen krisis terbagi menjadi tiga tahapan: pre crisis, crisis dan post crisis. Tahap pre crisis merupakan fase sebelum krisis terjadi, dimulai dengan mengumpulkan seluruh informasi tentang resiko, tindakan yang dilakukan ketika krisis terjadi, dan menyiapkan spokesperson (W.T. Coombs \& Holladay, 2010).

Menghadapi pandemi COVID-19, Universitas XXY menunjuk spokesperson atau juru bicara utama yaitu KH, Ketua Yayasan Pendidikan Universitas XXY, dan WU, Rektor Universitas XXY. Sedangkan spokesperson teknis, ditunjuk Direktur Kerja Sama dan Hubungan Masyarakat, AMBS beserta jajarannya.

Sebelum terjadi krisis sudah dilakukan monitoring media, sehingga pihak universitas dapat mendeteksi tindakan pencegahan. Sumber informasi yang didapat Universitas XXY terkait perkembangan virus COVID-19 berasal dari pemberitaan televisi, internet dan media sosial. Informan KH, dan WU juga menyampaikan himbauan untuk melakukan pencegahan penyebaran virus COVID-19. Hal ini dapat dilihat pada pemberitaan Kompas.com: "Tanggap Corona, Universitas XXY Bagi Masker dan Jamu Gratis" tanggal 09 Maret 2020. Informasi lainnya juga di dapat di media sosial Instagram Kampus Universitas XXY tanggal 17 Maret 2020. 
Saat isu soal COVID-19 menyebar, spokesperson memiliki peran penting untuk menghadapi media dan memberikan informasi kepada publik. Pemberitaan Kompas.com, tentang kampus XXY membagikan masker dan memberikan jamu secara gratis kepada warga kampus dan pengendara yang lewat di depan kampus, merupakan bentuk kampanye untuk menjaga kesehatan bersama dan mencegah virus corona.

Sedangkan untuk informasi pada media sosial Instagram Kampus XXY, juru bicara memberikan arahan kepada publik khususnya kepada warga kampus untuk dapat menjaga kesehatan dan tetap berada di rumah (stay at home), menjaga jarak sosial (social distancing), jangan panik, dan tetap menjaga produktivitas belajar di rumah. Pada informasi melalui media sosial Instagram dapat diketahui adanya kebijakan yang dikeluarkan oleh Universitas XXY yaitu pengalihan pembelajaran dari tatap muka (luring) menjadi pembelajaran dari rumah secara online (daring).

Pada tahap crisis dianalisis bagaimana proses tanggung jawab yang dilakukan oleh Universitas XXY sebagai upaya penanganan krisis. Situational Crisis Communication Theory terdiri dari beberapa elemen yaitu crisis responsibility, crisis history, prior reputations, crisis response strategies, affect, organization reputation dan behavioral intentions. Elemen pertama yaitu crisis responsibility, yang menjelaskan jenis krisis untuk melihat tanggung jawab serta ancaman yang diterima oleh organisasi ketika terjadi krisis. Pandemi COVID-19 termasuk krisis accidental yaitu peristiwa yang terjadi bukanlah kesengajaan yang dilakukan organisasi. Dengan kata lain tidak mempunyai maksud menyebabkan terjadinya krisis.

Crisis history merupakan proses untuk menganalisis jika organisasi pernah mengalami krisis serupa di masa lalu. Universitas XXY pernah mengalami krisis, yaitu musibah banjir awal tahun 2019. Area kampus tergenang air setinggi 1,5 meter. Ketika itu kerugian yang dialami mencakup dokumen berharga dan peralatan kerja. Bentuk tangggung jawab kampus dapat dirasakan dengan pemindahan beberapa ruangan di lantai dasar ke lantai atas, kemudian mengganti semua peralatan yang rusak.

Berikutnya adalah elemen prior relations yang menurut W.T. Coombs \& \& Holladay (2010) merupakan proses bagaimana hubungan dan perlakuan organisasi dengan stakeholder. Dalam penanganan situasi pandemi COVID-19, Universitas XXY bekerjasama dengan beberapa stakeholder, antara lain Satuan Polisi Pamong Praja (Satpol PP), Kepolisian Petukangan Utara Jakarta Selatan, Dinas Lalu Lintas dan Angkutan Jalan Raya (DJJAJR).

Masing-masing stakeholder mempunyai peran dalam penanganan pandemi COVID-19 di Universitas XXY. Satpol PP dan Kepolisian Petukangan Utara mendirikan posko keamanan di depan kampus. Mereka mengamankan warga yang tidak menerapkan protokol kesehatan. DLLAJR bertugas mengecek dan mengontrol penggunaaan protokol kesehatan bagi warga yang melakukan perjalanan menggunakan angkutan umum dan melintas di depan Kampus XXY. Pihak keamanan internal Universitas $X X Y$, bertugas mengecek suhu, penggunaan masker, dan penyemprotan cairan desinfektan kepada karyawan, dosen, masyarakat yang memasuki kampus.

Crisis Response Strategy memiliki tujuan untuk menentukan tanggapan yang diberikan oleh organisasi saat terjadi krisis. Hasil analisis menunjukkan, Universitas XXY memilih tindakan diminish, yaitu tindakan untuk mengurangi dampak negatif dari peristiwa krisis. Hasil analisis menunjukkan sebagai upaya penanganan COVID-19, Universitas XXY mengambil tindakan yakni bekerja sama dengan pengurus RW dan RT kampus, media pemberitaan online, penyebaran siaran pers melalui website, berkomunikasi dengan pemerintahan daerah, kepolisian, dinas perhubungan, serta memanfaatkan media tradisional dan digital.

Kriyantono (2012) menyatakan, pada Situational Communication Crisis Theory, perusahaan 
harus berurusan dengan dampak krisis. Informasi terkait karyawan atau dosen yang terjangkit virus COVID-19 didapat jika yang bersangkutan melaporkan diri ke atasannya. Media yang digunakan untuk pemberitaan ini berupa WhatsApp Group (WAG) di masing-masing Biro atau Fakultas. Ketika ada karyawan maupun dosen yang terkonfirmasi positif COVID-19, pihak Universitas XXY harus mencek kebenaran informasi tersebut.

Selanjutnya jika data karyawan atau dosen tersebut positif terinfeksi COVID-19, maka pihak Universitas XXY mengambil tindakan; melakukan penelusuran (tracer) terhadap karyawan yang pernah bertemu atau kontak dengan pasien. Selanjutnya, karyawan/dosen yang terkonfirmasi melakukan kontak dengan korban/pasien diwajibkan menjalankan test Swab. Jika hasilnya positif, wajib melapor ke pihak universitas.

Untuk pasien yang positif COVID-19, pihak kampus lalu mengurus administrasi pengobatan pasien melalui asuransi kesehatan yang telah diberikan kepada setiap karyawan maupun dosen Universitas XXY. Di sisi lain, mahasiswa yang orang tuanya terdampak COVID-19, diberikan keringanan cicilan biaya perkuliahanan berupa waktu perpanjangan pembayaran cicilan.

Universitas XXY juga menggunakan new media seperti Instagram, Youtube, dan Facebook berisi himbauan untuk mencegah penyebaran COVID-19 di kampus dengan narasumber para petinggi Universitas XXY dan para mahasiswa.

Pada tahapan affect di dalam Situational Communication Crisis Theory dilihat bagaimana pengaruh krisis pada reputasi organisasi dan behavior intentions dari publik. Dampak yang ditimbulkan memang tidak ada hasil risetnya, tetapi setelah kegiatan manajemen krisis dilakukan, masyarakat kampus XXY menjadi lebih mengetahui perkembangan di kampus terkait situasi pandemi COVID-19.

Tahap terakhir manajemen krisis, post-crisis yaitu tahap pembelajaran yang diterima organisasi setelah terjadinya krisis, serta tindakan komunikasi yang dilakukan oleh organisasi setelah krisis terjadi. Tindakan komunikasi yang dilakukan oleh Universitas XXY yaitu berupa sejumlah kebijakan yang diambil dalam pencegahan penyebaran COVID-19. Tindakan komunikasi diawali dengan diskusi di tingkat petinggi Universitas XXY untuk menentukan kebijakan yang harus diambil.

Kebijakan tersebut antara lain membatasi jumlah pengunjung atau tamu untuk kegiatan yang bersifat umum seperti urusan administrasi, pengalihan sistem belajar luring menjadi daring sejak Semester Gasal 2020/2021 dan semester Genap 2020/2021, membatasi jumlah karyawan/dosen masuk kerja, memperpanjang kegiatan WFH.

Hasil analisis menunjukkan dengan adanya kebijakan yang dibuat Universitas XXY dan dengan adanya penyampaian informasi melalui surat edaran dan memo internal, dapat menurunkan sentimen negatif masyarakat kampus dan mengurangi rasa cemas meskipun harus tetap waspada dalam menjalankan kegiatan.

\section{KESIMPULAN}

Tindakan manajemen krisis yang dilakukan oleh Universitas XXY pada tahapan pre-krisis, adalah melakukan monitoring media, penentuan spokesperson, dan pertemuan dengan para stakeholder. Crisis responsibility yang dialami termasuk ke dalam jenis crisis accidental, dan Universitas XXY melaksanakan tanggungjawabnya terhadap Karyawan, Dosen, dan Mahasiswa.

Universitas XXY menggunakan strategi cross check informasi dan memberikan bentuk-bentuk pertanggungjawaban dan memilih tindakan diminish untuk mengurangi dampak negatif dari peristiwa krisis. Pada tahap affect, setelah kegiatan manajemen krisis dilakukan, masyarakat kampus menjadi lebih tahu tentang perkembangan terbaru situasi pandemi COVID-19 di kampus. 
Pada tahap post-crisis, tindakan komunikasi yang dilakukan Universitas XXY adalah penerapan sejumlah kebijakan yang diambil dalam rangka pencegahan penyebaran COVID-19. Saat krisis melanda (prior reputation), hubungan yang dimiliki organisasi dengan para stakeholder harus dapat dimanfaatkan. Peristiwa krisis tidak bisa terselesaikan jika hanya mengandalkan satu organisasi. Dibutuhkan kerja sama dan komunikasi kepada stakeholder untuk membantu dan melakukan penanganan krisis secara bersama-sama. Kejelasan informasi dan tindakan komunikasi juga merupakan hal penting dalam manajemen krisis.

\section{DAFTAR PUSTAKA}

Buana, R. D. (2020). Analisis Perilaku Masyarakat Indonesia dalam Menghadapi Pandemi COVID-19 dan Kiat Menjaga Kesejahteraan Jiwa. Sosial Dan Budaya, Fakultas Syariah Dan Hukum Universitas Islam Negeri (UIN) Syarif Hidayatullah Jakarta, 53(9), 1689-1699. file://C:/Users/User/Downloads/fvm939e.pdf

C. Sohrabi, et all. (2020). World Health Organization declares global emergency: A review of the 2019 novel coronavirus (COVID-19). International Journal of Surgery. google scholar

Kemkes. (2020). Novel Corona Virus. https://kemkes.go.id

Kompas.com. (2020a). Perjalanan Kasus Virus Corona di Indonesia. Www.Kompas.Com. https://www.kompas.com/tren/read/2020/09/02/073000465/perjalanan-kasus-virus-

corona-di-indonesia-?page=all\#: :text=2 Maret 2020\%2C Presiden Joko,COVID-19 menjadi 34 orang.

Kompas.com. (2020b). Perkembangan Virus Corona. https://www.detik.com

Kriyantono, R. (2012). Public Relations \& Crisis Management: Pendekatan Critical Public Relations Etnografi Kritis \& Kualitatif. Kencana.

Turner, Lynn H and West, R. (2010). Introducing Communication Theory: Analysis and Application (4th ed.). McGraw-Hill.

W.T. Coombs \&, \& Holladay, S. J. (2010). Parameters for Crisis Communication. In The Handbook of Crisis Communication. West Sussex: Wiley-Blackwell.

Yulianti, W., \& Boer, R. F. (2020). Manajemen krisis public relations dalam menangani penolakan imunisasi measles rubella. PRofesi Humas Jurnal Ilmiah Ilmu Hubungan Masyarakat, 4(2), 290. https://doi.org/10.24198/prh.v4i2.23700 